\title{
Perancangan Produk Penunjang Aktivitas di Masa Normal Baru Berbahan Printing Canvas untuk Omorfa Matia
}

\author{
Arumelia Krismoniqasari, Bayyinah Nurrul Haq, dan Aam Bastaman \\ Desain Produk, Fakultas Industri Kreatif dan Telematika, Universitas Trilogi, Jakarta, Indonesia \\ e-mail: arumeliaa@gmail.com
}

\begin{abstract}
Abstrak-Usaha Kecil dan Menengah (UKM) merupakan usaha ekonomi produktif yang berdiri sendiri atas inisiatif seseorang atau sekelompok orang. Saat ini banyak UKM yang menjual produk yang dapat memenuhi kebutuhan saat berpergian pada masa normal baru dengan menggunakan teknologi digital printing salah satunya UKM Omorfa Matia. Tulisan ini membahas dari perancangan produk yang berupa satu rangkaian koleksi terdiri dari tote bag, masker, face shield, strap, dan tempat hand sanitizer untuk UKM Omorfa Matia. Perancangan ini melalui beberapa tahapan yaitu tahapan penelitian awal yang meliputi kegiatan pengumpulan data dengan teknik observasi, wawancara, dan pengumpulan data dari berbagai sumber. Data lapangan dianalisis menggunakan analisa SWOT, Space Matriks, IFAS EFAS, BCG, Benchmark Wheel, untuk mendapatkan rekomendasi yang akan dijadikan konsep desain yang sesuai kebutuhan pasar. Pengembangan konsep dilakukan dengan Metode Scamper. Hasil dari perancangan ini adalah produk tote bag, masker, face shield, strap, dan tempat handsanitizer tas yang inovatif berbahan printing canvas yang dapat digunakan untuk berpergian ke luar rumah.
\end{abstract}

Kata Kunci- normal baru, pencetakan digital, tote bag Usaha Kecil dan Menengah (UKM)

\begin{abstract}
Small and Medium Enterprises (SMEs) are productive economic ventures that are self-founded on the contribution of a person or group of people. Currently, there are many SMEs sell products that can meet the needs when traveling in new normal times by using digital printing technology, one of them is Omorfa Matia. This paper discusses the product design in the form of a series of collections consisting of tote bags, masks, face shields, straps, and a hand sanitizer for Omorfa Matia SMEs. This design went through several stages which included the above research which included data collection activities with observation, interview, and data collection techniques from various sources. Field data were analyzed using SWOT analysis, Space Matrix, IFAS EFAS, BCG, Benchmark Wheel, to get updates which will be according to the design concept that suits the market needs. Concept development is carried out using the SCAMPER Method. The results of this design are products of tote bags, masks, face shields, straps, and an innovative handheld bag holder with canvas printing material that can be used to travel outside the home.
\end{abstract}

Keywords - new normal, digital printing, tote bag, Small and Medium Enterprises (SMEs)

\section{PENDAHULUAN}

UKM tidak akan mampu bersaing jika tidak berbenah dan mengejar ketertinggalan dari produk-produk pesaing, terutama produk yang sedang diperlukan dipasaran. Maka perlu adanya perbaikan dalam proses produksi maupun inovasi-inovasi lain yang dapat membantu daya saing UKM [1]. Saat ini banyak UKM fesyen mengunakan bahan baku tekstil dengan motif yang dihasilkan lewat cetak digital [2] Keunggulan dari produk dengan bahan baku tekstil dengan motif cetak digital adalah memiliki motif yang eksklusif dirancang dan tidak diproduksi secara massal, dan motif dapat dirancang tanpa batas kreativitas [3].

Salah satu UKM yang memiliki ciri khas pada motif hasil cetak digital adalah Omorfa Matia. Mulai berproduksi tahun 2017 dan menjualnya secara daring lewat media sosial dan market place. Persaingan produk dengan bahan baku yang menggunakan cetak digital semakin ketat. Hingga tahun 2020 , tercatat $+/-100$ pcs penjual tote bag kanvas dengan motif cetak digital. Sebagian membuat motifnya secara khusus, sebagian lagi mengambil dari motif yang sudah ada.

Salah satu kebutuhan yang muncul sejak terjadinya pandemic Covid-19 adalah diberlakukannya cara menjalani hidup yang sesuai dengan protokol $\mathrm{WHO}$, hal ini sering disebut dengan "New Normal". Menurut keputusan Kementrian Kesehatan nomor HK.01.07/MENKES/ 382/2020 tentang protokol kesehatan bagi masyarakat di tempat dan fasilitas umum, hal yang harus dipatuhi selama berada di area public adalah memastikan diri dalam kondisi sehat, menggunakan masker saat perjalanan dan selama berada di tempat umum, menggunakan handsanitizer, social distancing, tidak menyentuh area wajah, dan penggunaan face shiel [4].

Kondisi ini memunculkan kebutuhan pasar akan tersedianya produk-produk penunjang aktivitas di era $\mathrm{New}$ Normal. Hal ini dapat dijadikan sebagai peluang bagi UKM, terutama yang bergerak di bidang garmen yang memproduksi pakaian atau aksesoris berbahan tekstil. Omorfa Matia merupakan UKM yang bergerak dibidang pembuatan produk berbahan tekstil digital print dengan motif karya beberapa pelukis. Bahan tersebut dijadikan aneka tote bag. Menghadapi munculnya kebutuhan akan produk penunjang di masa normal baru maka UKM Omorfa Matia perlu melakukan inovasi produk yang sesuai dengan kondisi pasar. 
Tujuan dari perancangan ini adalah merancang produk yang dibutuhkan untuk memenuhi kebutuhan normal baru (new normal) yaitu tote bag, masker, face shield, strap, dan tempat handsanitizer untuk UKM Omorfa Matia.

\section{METODE}

Penelitian diperlukan untuk mengembangakan pengetahuan, yang merupakan suatu usaha untuk menyelidiki masalah tertentu yang memerlukan jawaban. Dalam penelitian ini peneliti menggunakan metode penelitian kualitatif sebagai acuan penelitian [5]. Gambar 1 menjelaskan proses alur perancangan riset ini.

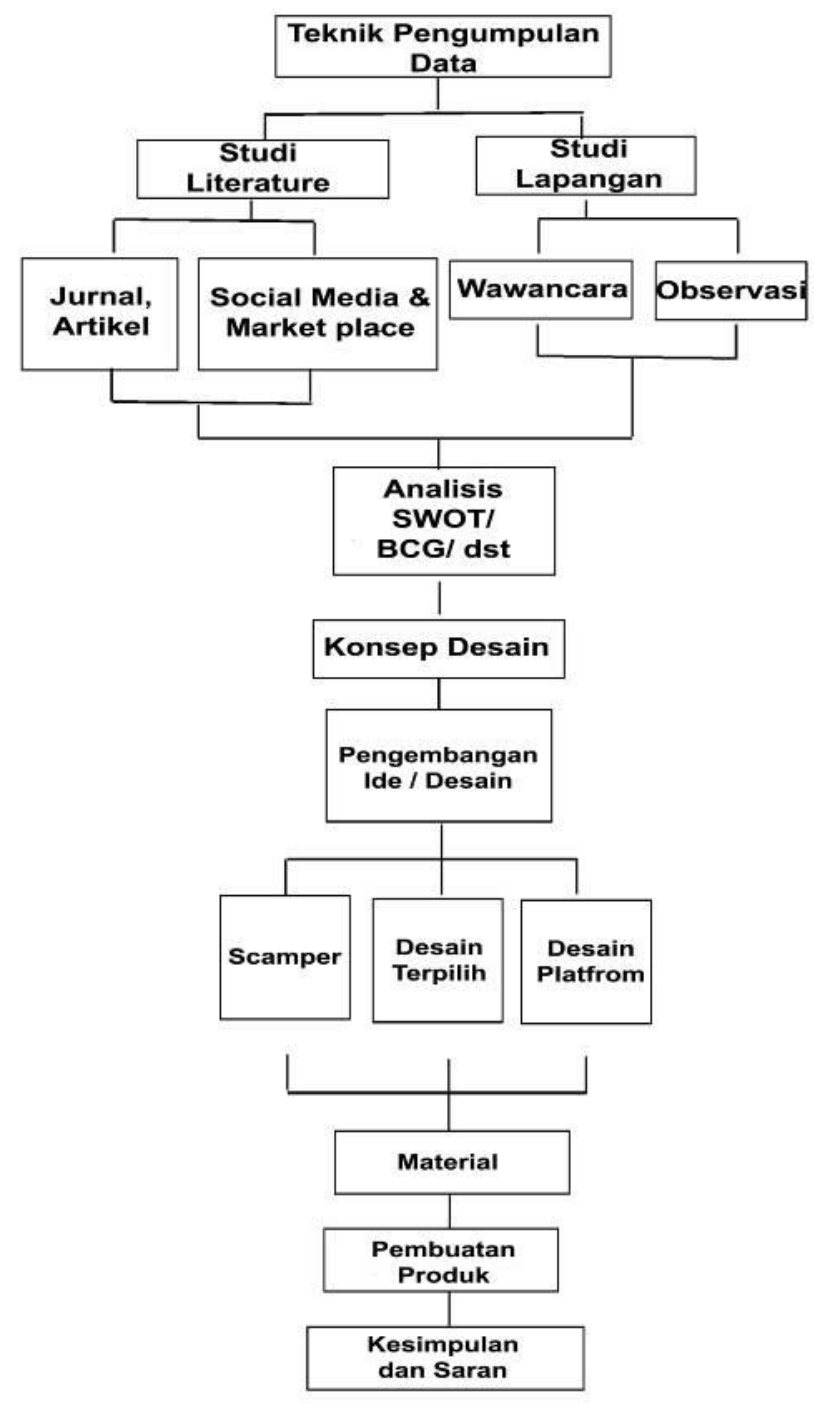

Gambar 1. Diagam Alir pada Alur Perancangan.

\section{Teknik Pengumpulan Data}

Teknik atau metode yang digunakan untuk mengumpulkan data dalam penelitian ini yaitu studi literatur dan studi lapangan.

\section{A. Studi Literatur}

Studi literatur adalah serangkaian kegiatan yang berkenaan dengan metode pengumpulan data pustaka, membaca dan mencatat, serta mengelolah bahan penelitian [6]. Peneliti melakukan pencarian dari sumber buku, artikel, jurnal, dan juga dokumen, social media, data penjualan dari market place (tokopedia dan shopee) yang relevan dengan permasalahan.

\section{B. Studi Lapangan}

Studi lapangan berupa wawancara langsung dan wawancara lewat whatsapp pada pemilik UKM Omorfa Matia di daerah Bandung, Jawa Barat dan melakukan observasi ke tempat pembuatan produk dari UKM Omorfa Matia. Tujuan wawancara dan observasi, untuk mencari data agar mendapat informasi yang akurat dan sesuai dengan yang dicari.

Wawancara dilaksanakan kepada pemilik UKM Omorfa Matia di daerah Bandung, Jawa Barat tentang profil UKM, marketing mix, manajemen produksi, dan manajemen keuangan

Observasi dilaksanakan ke tempat pembuatan produk dari UKM Omorfa Matia tentang alat apa saja yang digunakan untuk produksi dan pemasaran. Mekanisme pemotretan lukisan yang akan dicetak pada kain kanvas dan bagaimana proses pembuatan produk dari awal hingga selesai.

\section{Teknik Analisa Data \\ Analisis SWOT}

Teknik ini digunakan untuk mendapatkan gambaran tentang kekuatan, kelemahan, yang dimiliki, serta peluang, ancaman yang didapat dan dihadapi oleh UKM.

\section{Analisis IFAS \& EFAS}

Teknik ini digunakan untuk menganalisis faktor strategi pengolahan data faktor strategis pada lingkungan internal dan eksternal dengan memberikan pembobotan dan menetapkan rating pada setiap faktor strategisnya [7].

\section{Analisis Matrix Space}

Teknik ini digunakan untuk mendapatkan hasil analisis berupa posisi strategi dan evaluasi tindakan agar dapat menentukan aspek-aspek agresive, konservatif, defensif, atau kempetitif [7].

Analisis T-O-W-S (S-W-O-T)

Teknik ini digunakan untuk mendapatkan hasil analisis T-OW-S dengan menggunakan data hasil dari SWOT, analisa T$\mathrm{O}-\mathrm{W}-\mathrm{S}$ ini dibagi menjadi 4 bagian yaitu:

a. ST: hasil kesimpulan beberapa analisis dari strength dan threats

b. SO: hasil kesimpulan beberapa analisis dari strength opportunity

c. WT: hasil kesimpulan beberapa analisis dari weakness dan threats

d. WO: hasil kesimpulan beberapa analisis dari weakness dan opportunity

\section{Analisis BCG}

Teknik ini digunakan untuk mendapatkan hasil analisis BCG dengan menyusun dan menghitung kenaikan pertumbuhan pasar pertahun dan pertahun sebelumnya serta pangsa pasar per produk UKM dan penjualan data per produk pesaing. Setelah pangsa pasar dan kenaikan pertumbuhan didapat lalu kemudian dimasukkan ke dalam salah satu dari empat kuadran matriks BCG yaitu yaitu Star, Question Mark, Cash Cow, Dog [8].

\section{Benchmark Wheel}

Teknik ini digunakan untuk mendapatkan hasil strategi untuk menentukan Gap yang ada dengan cara membandingkan UKM dengan pesaingnya agar dapat 


\begin{tabular}{|c|c|}
\hline S (Kekuatan) & W (Kelemahan) \\
\hline $\begin{array}{l}\text { 1. Memiliki tempat produksi sendiri } \\
\text { 2. Motif pada produk hasil rancangan pelukis terkenal } \\
\text { 3. Membuat desain produk sendiri } \\
\text { 4. Memiliki karyawan professional dibidangnya } \\
\text { 5. Bahan yang digunakan termasuk kualitas tinggi (grade } \\
\text { terbaik) } \\
\text { 6. Produk bisa dijual online dengan cara menyetok barang } \\
\text { 7. Bahan baku mudah didapatkan karena di produksi } \\
\text { sendiri }\end{array}$ & $\begin{array}{l}\text { 1. Pendapatan hanya dari online store } \\
\text { 2. Tidak dapat menerima pesanan produk custom } \\
\text { 3. Tidak punya offline store } \\
\text { 4. Bentuk produk tidak berubah atau standar (umum ) }\end{array}$ \\
\hline O (Peluang) & $\begin{array}{l}\text { T (Ancaman) } \\
\end{array}$ \\
\hline $\begin{array}{l}\text { 1. Mendapatkan dukungan dari pemerintah Kota Bandung } \\
\text { karena produk lokal } \\
\text { 2. Tren bahan kanvas semakin meningkat }\end{array}$ & $\begin{array}{l}\text { 1. Pesaing banyak menggunakan produk sejenis } \\
\text { 2. Persaingan harga dengan brand lain yang lebih murah }\end{array}$ \\
\hline
\end{tabular}

\begin{tabular}{|c|c|}
\hline Faktor Internal & Faktor Eksternal \\
\hline $\begin{array}{l}\text { 1. Memiliki tempat produksi sendiri } \\
\text { 2. Motif pada produk hasil rancangan pelukis terkenal } \\
\text { 3. Membuat desain produk sendiri } \\
\text { 4. Memiliki karyawan professional dibidangnya } \\
\text { 5. Bahan yang digunakan termasuk kualitas tinggi (grade } \\
\text { terbaik) } \\
\text { 6. Produk bisa dijual online dengan cara menyetok } \\
\text { barang } \\
\text { 7. Bahan baku mudah didapatkan karena di produksi } \\
\text { sendiri } \\
\text { 8. Pendapatan hanya dari online store } \\
\text { 9. Tidak dapat menerima pesanan produk custom } \\
\text { 10.Tidak punya toko offline resmi / tetap } \\
\text { 11.Bentuk produk tidak berubah atau standar (umum ). }\end{array}$ & $\begin{array}{l}\text { 1. Mendapatkan dukungan dari pemerintah kota } \\
\text { Bandung karena produk lokal } \\
\text { 2. Tren bahan kanvas semakin meningkat } \\
\text { 3. Produk bisa dijual online dengan cara menyetok } \\
\text { barang } \\
\text { 4. Bahan baku mudah didapatkan karena di produksi } \\
\text { sendiri } \\
\text { 5. Pesaing banyak menggunakan produk sejenis } \\
\text { 6. Persaingan harga dengan brand lain yang lebih murah }\end{array}$ \\
\hline
\end{tabular}

memahami, memperbaiki dan mengevaluasi proses produk saat ini sehingga dapat menemukan cara untuk meningkatkan kualitas produk.

\section{HASIL DAN PEMBAHASAN}
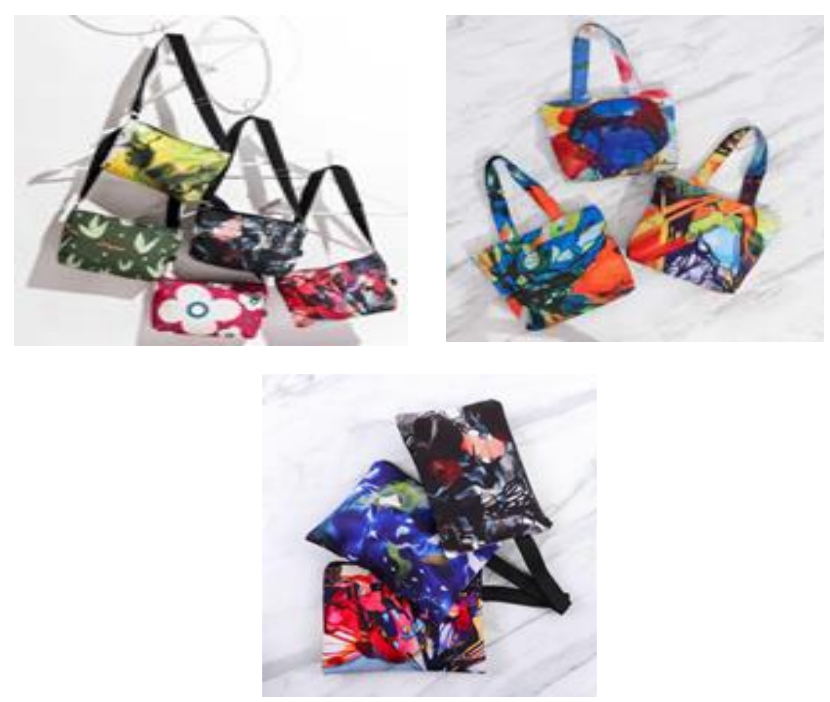

Gambar 2. Contoh Produk dari UKM Omorfa Matia. Sumber: Omorfa Matia

\section{Profil UKM}

UKM Omorfa Matia merupakan salah satu UKM yang berlokasi di Bandung. UKM ini hanya melakukan penjualan secara online melalui:

Instagram: omorfamatiaid;

Shopee : omorfa_matia; dan

Website : http://shop.tokotalk.com/omorfamatia

\section{Produk Omorfa Matia}

Gambar 2 menunjukkan beberapa contoh produk yang telah diproduksi oleh UKM Omorfa Matia

\section{Analisa SWOT}

Untuk menggambarkan kondisi UKM Omorfa Matia pada saat ini, maka dilakukan analisis pada UKM. Penelitian ini membutuhkan data faktor-faktor internal dan eksternal yang mempengaruhi UKM Omorfa Matia. Berikut merupakan faktor kekuatan, kelemahan, peluang dan ancaman bagi UKM Omorfa Matia (Tabel 1).

\section{Matriks IE}

Analilis terhadap faktor internal UKM Omorfa Matia dilakukan dengan menggunakan matriks Internal Factor Evaluation (IFE) dan faktor eksternal dianalisis dengan menggunakan matriks External Factor Evaluation (EFE, Tabel 2).

Tabel 3 menunjukkan hasil perhitungan skor IFE. Hasil perkalian antara rataan bobot dan rating, total skor yang dihasilkan pada matriks IFE adalah 2,95.

Tabel 4 menunjukkan hasil perhitungan skor EFE. Hasil perkalian antara rataan bobot dan rating, total skor yang dihasilkan pada matriks EFE adalah 2,44.

Gambar 3 menunjukkan nilai EFAS dan IFAS Matriks UKM Omorfa Matia adalah 2,44 dan 2,95 maka berada pada posisi kuadran V artinya berada di posisi "stabilitaspertumbuhan" sehingga strategi yang tepat untuk UKM Omorfa Matia adalah pengembangan pasar produk dan penetrasi pasar (lihat Tabel 5) 
Perancangan Produk Penunjang Aktivitas di Masa Normal Baru Berbahan Printing Canvas untuk Omorfa Matia Arumelia Krismoniqasari, Bayyinah Nurrul Haq, dan Aam Bastaman

Tabel 3. IFE Omorfa Matia

\begin{tabular}{|c|c|c|c|c|}
\hline \multicolumn{2}{|c|}{ Strength } & Bobot & Rating & Skor \\
\hline S.1 & Memiliki tempat produksi sendiri & 0.10 & 3 & 0.30 \\
\hline S.2 & Motif pada produk hasil rancangan pelukis terkenal & 0.13 & 4 & 0.52 \\
\hline S.3 & Membuat desain produk sendiri & 0.11 & 3 & 0.33 \\
\hline S.4 & Memiliki karyawan professional dibidangnya & 0.10 & 4 & 0.40 \\
\hline S.5 & Bahan yang digunakan termasuk kualitas tinggi (grade terbaik) & 0.09 & 3 & 0.27 \\
\hline S.6 & Produk bisa dijual online dengan cara menyetok barang & 0.07 & 3 & 0.21 \\
\hline S.7 & Bahan baku mudah didapatkan karena di produksi sendiri & 0.09 & 4 & 0.36 \\
\hline \multicolumn{2}{|r|}{ Sub Total Strength } & 0.69 & & 2.39 \\
\hline \multicolumn{2}{|c|}{ Weakness } & Bobot & Rating & Skor \\
\hline W.1 & Pendapatan hanya dari online store & 0.06 & 1 & 0.06 \\
\hline W.2 & Tidak dapat menerima pesanan produk custom & 0.08 & 2 & 0.16 \\
\hline W.3 & Tidak punya toko offline resmi / tetap & 0.10 & 2 & 0.20 \\
\hline $\mathrm{W} .4$ & Bentuk produk tidak berubah atau standar (umum) & 0.07 & 2 & 0.14 \\
\hline \multicolumn{2}{|r|}{ Sub Total Weakness } & 0.31 & & 0.56 \\
\hline \multicolumn{2}{|r|}{ Total } & 1 & & 2.95 \\
\hline
\end{tabular}

Tabel. 4. EFE Omorfa Matia

\begin{tabular}{|c|l|c|c|c|}
\hline \multicolumn{1}{|c|}{ EFAS } & Bobot & Rating & Skor \\
\hline Oportunities & $\begin{array}{l}\text { Mendapatkan dukungan dari pemerintah kota Bandung karena } \\
\text { produk lokal }\end{array}$ & 0.24 & - & 0.72 \\
\hline O. 2 & Tren bahan kanvas semakin meningkat & 0.32 & - & 1.28 \\
\hline \multicolumn{1}{|c|}{ Sub Total Oportunities } & $\mathbf{0 . 5 6}$ & - & $\mathbf{2}$ \\
\hline Threat & & & \\
\hline T.1 & Pesaing banyak menggunakan produk sejenis & 0.17 & - & 0.17 \\
\hline T.2 & Persaingan harga dengan brand lain yang lebih murah & 0.27 & - & 0.24 \\
\hline \multicolumn{2}{|c|}{ Sub Total Threat } & $\mathbf{0 . 4 4}$ & - & $\mathbf{0 . 4 4}$ \\
\hline \multicolumn{2}{|c|}{ Total } & & $\mathbf{2 . 4 4}$ \\
\hline
\end{tabular}

Tabel 5. Space Matriks Omorfa Matia.

\begin{tabular}{|c|c|c|c|}
\hline Posisi Strategis Internal & Rating & Posisi Strategis External & Rating \\
\hline Kekuatan Keuangan (FS) & & Stabilitas Lingkungan (ES) & \\
\hline Pertumbuhan Pendapatan & 5 & Persaingan industri yang makin ketat & -3 \\
\hline Rasio Likuiditas & 3 & Perkembangan teknologi informasi (internet) & -5 \\
\hline Profit Margin & 4 & $\begin{array}{l}\text { Ketersediaan produk yang bergantung pada harga } \\
\text { murah yang ditawarkan dealer }\end{array}$ & -2 \\
\hline Total Aset Perusahaan & 4 & Stabilitas Politik & -3 \\
\hline RATA - RATA & 4,0 & RATA - RATA & $-3,25$ \\
\hline Keunggulan Kompetitif $\quad(\mathrm{CA})$ & & Kekuatan Industri (IS) & \\
\hline $\begin{array}{l}\text { Kerjasama yang baik dengan pemasok bahan } \\
\text { baku (mendapatkan prioritas bahan model baru ) }\end{array}$ & -1 & Laba Usaha & 3 \\
\hline Pangsa pasar yang luas dan potensial & -1 & Perkembangan Permintaan Pasar & 4 \\
\hline Kualitas Produk & -1 & Pangsa pasar yang luas & 5 \\
\hline Kesetian pelanggan & -1 & SDM yang tersedia & 4 \\
\hline RATA - RATA & -1 & RATA - RATA & 4,0 \\
\hline
\end{tabular}

Skor Bobot Total IFA 2,95

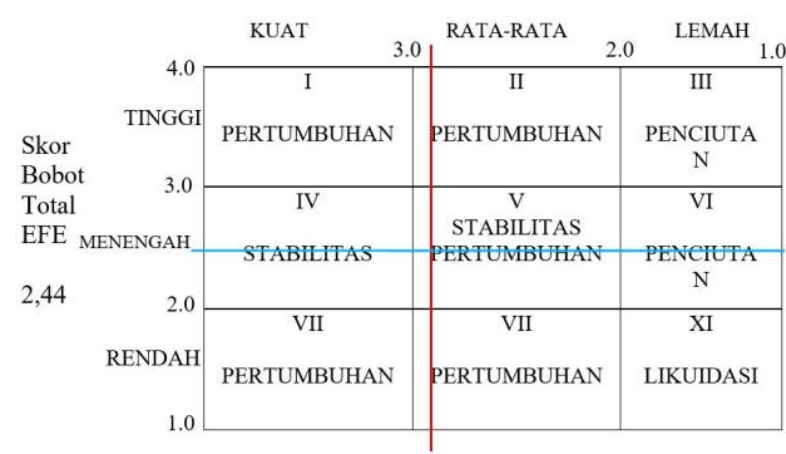

Gambar 3. Posisi UKM Omorfa Matia pada Matriks IE

Sumbu $\mathbf{X}=$ Rata-rata CA + Rata-rata IS

$=-1+4.0$

$=3$
Sumbu Y= Rata-rata FS + Rata-rata ES

$$
=4.0+-3,25
$$$$
=0,75
$$

$(\mathbf{X}, \mathrm{Y}) \quad=(3.0 ; 0,75)$

Berdasarkan hasil analisis yang dilakukan maka koordinat dari Omorfa matia terletak pada kuadran I (aggressive) maka sebaiknya menggunakan strategi sebagai berikut (Gambar 4):

1. Mengembangkan produk versi baru

2. Meningkatkan promosi

3. Pemutakhiran model produk lebih sering, agar lebih mengikuti tren

4. Mengikuti aneka pameran agar pembeli bisa melihat produk secara langsung 


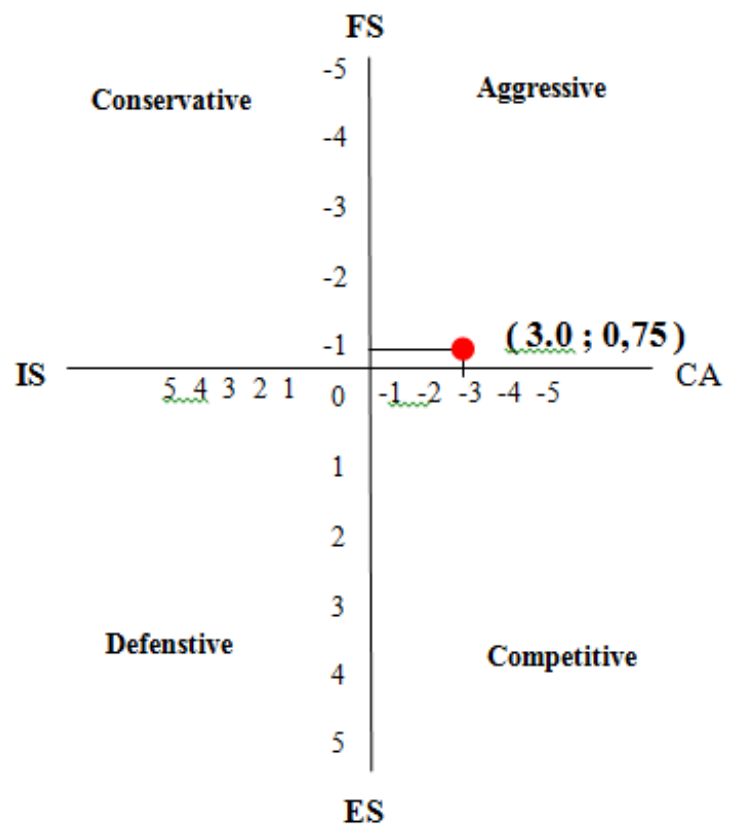

Gambar 4. Space Matriks UKM Omorfa Matia

\section{Matriks SWOT}

Matriks SWOT merupakan alat yang dapat membantu proses penyusunan dan pengembangan strategi. Faktorfaktor yang digunakan dalam proses pengembangan strategi adalah Strengths-Weakness-Opportunity-Threats. Strategi yang dibentuk menggunakan matriks SWOT dapat dilihat pada Tabel 6 .

Tabel 6. Strategi SWOT Omorfa Matia

\begin{tabular}{|c|c|c|}
\hline & $\mathrm{S}$ & $\mathrm{W}$ \\
\hline $\mathrm{O}$ & $\begin{array}{l}\text { SO } \\
\text { - Tren bahan kanvas yang } \\
\text { semakin meningkat } \\
\text { membuat bahan kanvas yang } \\
\text { digunakkan memiliki } \\
\text { kualitas yang tinggi }\end{array}$ & $\begin{array}{l}\text { WO } \\
\text { - Membuka offline store } \\
\text { - Dapat membuat produk custom } \\
\text { supaya konsumen dapat } \\
\text { memiliki produk bahan kanvas } \\
\text { yang disukai }\end{array}$ \\
\hline $\mathrm{T}$ & $\begin{array}{l}\text { ST } \\
\text { - Memiliki karyawan yang } \\
\text { professional untuk membuat } \\
\text { produk yang inovatif } \\
\text { - Kualitas produk yang di } \\
\text { berikan bagus maka harga } \\
\text { yang ditawarkan agak mahal }\end{array}$ & $\begin{array}{l}\text { WT } \\
\text { Pering memperbaharui model } \\
\text { produk setiap produksi jenis } \\
\text { baru supaya pesaing tidak } \\
\text { mengikuti }\end{array}$ \\
\hline
\end{tabular}

\section{Analisa BCG}

\section{UMKM terpilih}

Produk Omorfa Matia yang di produksi adalah Tote bag, medium Sling bag, mini Sling bag, Pouch, Scarf, dengan daftar harga jual sebagai berikut :
a. Tote bag
: Rp. 300.000,-
b. Medium Sling bag : Rp. 250.000,-
c. Mini Sling bag : Rp. 200.000,-
d. Pouch
: Rp. 85.000,-
e. Scarf
: Rp. 185.000,-

\section{Pesaing}

Omorfa Matia bukan satu-satunya UKM yang menjual produk printing canvas, salah satu pesaing bagi Omorfa Matia adalah Ideku Handmade. Data yang digunakan untuk analisis BCG adalah volume penjualan dan total volume penjualan Omorfa Matia dan mitra pesaingnya.
Tahap berikutnya untuk menentukan letak produk pada kuadran BCG dengan menghitung tingkat pertumbuhan pasar dan pangsa relatif. Gambar 5 menjelaskan Matriks BCG UKM Omorfa Matia.

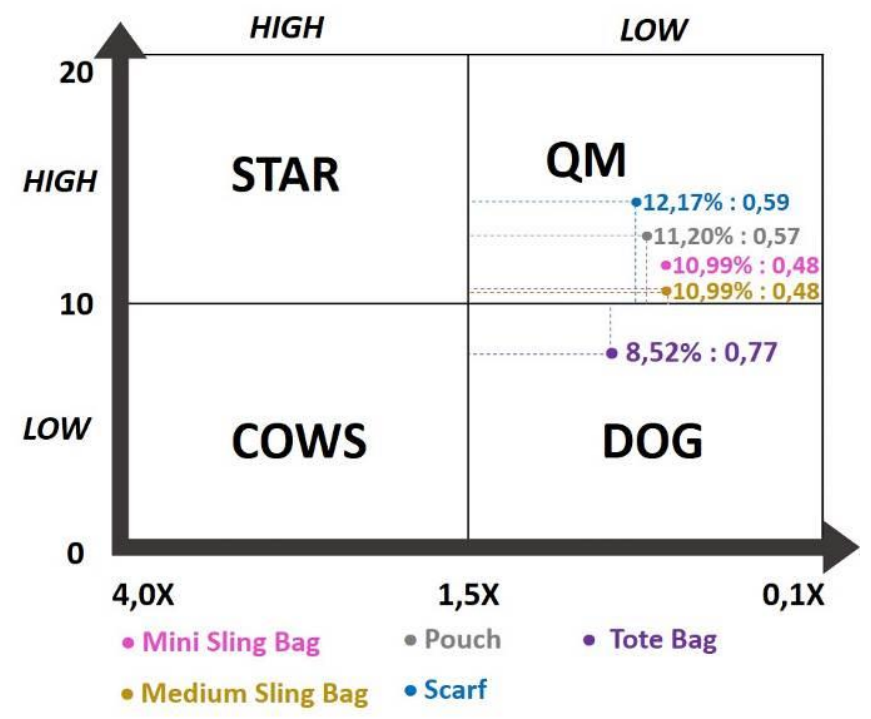

Gambar 5. Matriks BCG UKM Omorfa Matia

Dari hasil analisis BCG ini dapat disimpulkan bahwa Produk Tote bag Omorfa Matia berada pada kategori Dog. Walaupun produk tote bag ini termasuk pada kategori Dog, produk tote bag ini memiliki penjualan persentase tertinggi dan mengalami pengurangan minat pembeli tiap tahun. Maka agar produk tote bag ini harus tetap dikembangkan agar tidak mengalami penurunan minat konsumen. Oleh karena itu dibutuhkan inovasi pada tote bag. Cara untuk meningkatkan daya tarik adalah melalui peningkatan kualitas produk tote bag dan pengembangan desain dengan model baru yang unik dan menjawab kebutuhan pasar.

Benchmark Wheel

Benchmarking merupakan suatu proses pencarian secara berkelanjutan untuk suatu ide-ide dan metode-metode

\begin{tabular}{|c|c|c|c|}
\hline Toko & $\begin{array}{l}\text { Ideku } \\
\text { Handmade }\end{array}$ & $\begin{array}{l}\text { Kamalika } \\
\text { Artprint }\end{array}$ & Tropis ID \\
\hline Harga & Rp. 215.000,- & Rp. 425.000,- & $\mathrm{Rp}, 499.000,-$ \\
\hline Produk & & & $x+5 y=-6$ \\
\hline Material & $\begin{array}{l}\text { Printing Baby } \\
\text { Canvas, Strap } \\
\text { Synthetic } \\
\text { Leather }\end{array}$ & $\begin{array}{l}\text { Printing } \\
\text { Canvas, } \\
\text { Polyester } \\
\text { Canvas, Strap } \\
\text { Leather. }\end{array}$ & $\begin{array}{l}\text { Printing } \\
\text { Canvas, Canvas } \\
\text { Polos, Strap } \\
\text { Leather. }\end{array}$ \\
\hline Placement & Indonesia & Indonesia & $\begin{array}{l}\text { Indonesia dan } \\
\text { Luar Negeri }\end{array}$ \\
\hline Promosi & - & Diskon & - \\
\hline $\begin{array}{l}\text { Segmen } \\
\text { Pasar }\end{array}$ & $\begin{array}{l}\text { Wanita, usia } \\
18-35 \text { tahun, } \\
\text { mahasiswa, } \\
\text { wanita karir, } \\
\text { golongan } \\
\text { menengah ke } \\
\text { atas }\end{array}$ & $\begin{array}{l}\text { Wanita, usia } \\
18-35 \text { tahun, } \\
\text { mahasiswa, } \\
\text { wanita karir, } \\
\text { golongan } \\
\text { menengah ke } \\
\text { atas }\end{array}$ & $\begin{array}{l}\text { Wanita, usia 18- } \\
35 \text { tahun, } \\
\text { mahasiswa, } \\
\text { wanita karir, } \\
\text { golongan } \\
\text { menengah ke } \\
\text { atas. }\end{array}$ \\
\hline
\end{tabular}


baru, praktik dan proses, serta salah satu usaha mengadaptasi fitur terbaik, kemudian menerapkannya untuk memperoleh hasil terbaik [9]. Benchmarking yang dilakukan pada produk tote bag Omorfa Matia adalah:

Memilih mitra benchmark (Ideku Handmade, Kamalika Artprint, dan Tropis ID, Tabel 7).

Key performance indicator yang dipakai adalah teori Kotler \& Keller, Hermawan, Lilian tentang pemasaran dan tentang pengguna, produsen, perupaan / visual, serta fungsi (Tabel 8).

\section{Adaptasi}

a. Rekomendasi Pengguna

b. Rekomendasi Produsen / Produksi

c. Rekomendasi Fungsi

d. Rekomendasi Perupaan / Visual

e. Rekomendasi Pemasaran

f. Rekomendasi Sistem Distribusi

\section{Rekomendasi Produsen / Produksi}

Gambar 6 menjelaskan tentang fitur yang akan digunakan untuk produk dari UKM Omorfa Matia.

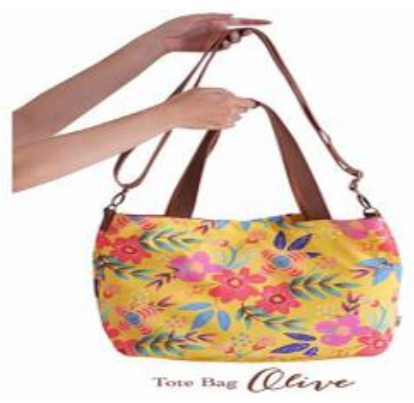

Gambar 6. Fitur pada Pesaing.

Bagian yang akan di adopsi dari produk pesaing Ideku Handmade adalah menambahkan ring D, kaitan pada bagian samping, memberikan tali panjang yang memiliki material kulit sintetis dan ring jalan dengan material black nickel.

\section{Rekomendasi Fungsi}

Gambar 7 menjelaskan tentang fitur lainnya yang akan di adopsi ke produk yaitu penambahan sekat pada bagian dalam tas dan beberapa kantong di dalam dan di luar tas.
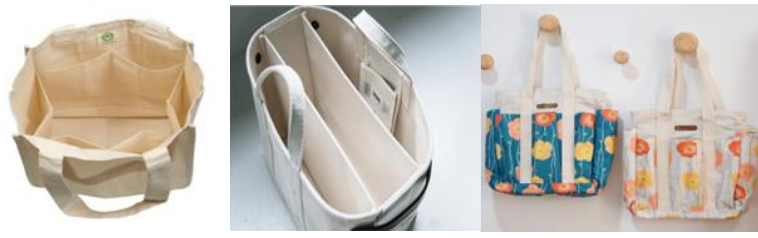

Gambar 7. Fitur Sekat Dalam Tas dan Kantong Bagian Samping

\section{Pengembangan Konsep Desain}

Berdasarkan hasil analisis maka disusunlah konsep pengembangan produk tote bag sebagai berikut:

1 (satu) set produk untuk masa new normal yaitu tote bag, strap, wadah hand sanitizer, masker dan face shield yang
Tabel 8. Search Pesaing.

\begin{tabular}{|c|c|c|c|c|}
\hline $\begin{array}{l}\text { Kompo } \\
\text { nen } \\
\text { Bench } \\
\text { mark }\end{array}$ & $\begin{array}{l}\text { Perfor } \\
\text { mance } \\
\text { Indicator }\end{array}$ & $\begin{array}{l}\text { Omorfa } \\
\text { Matia }\end{array}$ & $\begin{array}{l}\text { Ideku } \\
\text { Handmade }\end{array}$ & Tropis ID \\
\hline \multirow[t]{6}{*}{ Pengguna } & Geografis & Indonesia & Indonesia & $\begin{array}{l}\text { Indonesia } \\
\text { dan luar } \\
\text { negeri }\end{array}$ \\
\hline & Demografi & Wanita & Wanita & Wanita \\
\hline & Psikografi & $\begin{array}{l}\text { Pecinta } \\
\text { Produk } \\
\text { Lokal } \\
\end{array}$ & $\begin{array}{l}\text { Pecinta } \\
\text { Produk } \\
\text { Lokal } \\
\end{array}$ & $\begin{array}{l}\text { Pecinta } \\
\text { Produk } \\
\text { Lokal } \\
\end{array}$ \\
\hline & - & $\begin{array}{l}\text { Penggemar } \\
\text { desain unik/ } \\
\text { khas }\end{array}$ & $\begin{array}{l}\text { Penggemar } \\
\text { desain unik/ } \\
\text { khas }\end{array}$ & $\begin{array}{l}\text { Penggema } \\
\text { r desain } \\
\text { unik/ khas }\end{array}$ \\
\hline & - & $\begin{array}{l}\text { Penggemar } \\
\text { desain unik/ } \\
\text { khas }\end{array}$ & $\begin{array}{l}\text { Penggemar } \\
\text { desain unik/ } \\
\text { khas }\end{array}$ & $\begin{array}{l}\text { Penggema } \\
\text { r desain } \\
\text { unik/ khas }\end{array}$ \\
\hline & - & $\begin{array}{l}\text { Anggaran di } \\
\text { atas } 250 \text { ribu }\end{array}$ & $\begin{array}{l}\text { Anggaran di } \\
\text { bawah } 250 \\
\text { ribu }\end{array}$ & $\begin{array}{l}\text { Anggaran } \\
\text { di bawah } \\
250 \text { ribu }\end{array}$ \\
\hline \multirow[t]{5}{*}{$\begin{array}{l}\text { Produsen } \\
\text { / } \\
\text { Produksi }\end{array}$} & $\begin{array}{l}\text { Material / } \\
\text { Jenis } \\
\text { Material } \\
\end{array}$ & $\begin{array}{l}\text { Badan tas } \\
\text { printing } \\
\text { canvas } \\
\end{array}$ & $\begin{array}{l}\text { Badan tas } \\
\text { printing } \\
\text { canvas } \\
\end{array}$ & $\begin{array}{l}\text { Badan tas } \\
\text { printing } \\
\text { canvas } \\
\end{array}$ \\
\hline & & $\begin{array}{l}\text { Strap } \\
\text { Kanvas }\end{array}$ & $\begin{array}{l}\text { Strap } \\
\text { Synthetic } \\
\text { Leather }\end{array}$ & $\begin{array}{l}\text { Strap } \\
\text { Kanvas }\end{array}$ \\
\hline & & $\begin{array}{l}\text { Furing } \\
\text { Suede }\end{array}$ & $\begin{array}{l}\text { Furing } \\
\text { Spunbond }\end{array}$ & $\begin{array}{l}\text { Furing } \\
\text { Spunbond }\end{array}$ \\
\hline & $\begin{array}{l}\text { Mesin / } \\
\text { Jenis mesin } \\
\text { produksi }\end{array}$ & $\begin{array}{l}\text { Mesin untuk } \\
\text { print kain }\end{array}$ & $\begin{array}{l}\text { Mesin untuk } \\
\text { print kain }\end{array}$ & $\begin{array}{l}\text { Mesin } \\
\text { untuk print } \\
\text { kain }\end{array}$ \\
\hline & & Mesin Jahit & Mesin Jahit & $\begin{array}{l}\text { Mesin } \\
\text { Jahit }\end{array}$ \\
\hline \multirow[t]{3}{*}{ Fungsi } & Strap & $\begin{array}{l}\text { Strap } \\
\text { Pendek } \\
\text { untuk } \\
\text { membawa } \\
\text { tas di bahu } \\
\end{array}$ & $\begin{array}{l}\text { Strap } \\
\text { Pendek } \\
\text { untuk } \\
\text { membawa } \\
\text { tas di bahu } \\
\end{array}$ & $\begin{array}{l}\text { Strap } \\
\text { Pendek } \\
\text { untuk } \\
\text { membawa } \\
\text { tas di bahu }\end{array}$ \\
\hline & $\begin{array}{l}\text { Kompartem } \\
\text { en/ fitur } \\
\text { sekat }\end{array}$ & $\begin{array}{l}\text { Sekat } \\
\text { dibagian } \\
\text { dalam tas } \\
\end{array}$ & $\begin{array}{l}6 \text { Sekat } \\
\text { dibagian } \\
\text { dalam tas } \\
\end{array}$ & $\begin{array}{l}\text { Sekat } \\
\text { dibagian } \\
\text { dalam tas } \\
\end{array}$ \\
\hline & $\begin{array}{l}\text { Bahan } \\
\text { Kemasan }\end{array}$ & Plastik & Paperbag & Plastik \\
\hline \multirow[t]{8}{*}{$\begin{array}{l}\text { Strategi } \\
\text { Pema } \\
\text { Saran }\end{array}$} & $\begin{array}{l}\text { Jenis } \\
\text { Promosi }\end{array}$ & $\begin{array}{l}\text { Melakukan } \\
\text { progam } \\
\text { discount }\end{array}$ & $\begin{array}{l}\text { Melakukan } \\
\text { progam } \\
\text { discount } \\
\text { serta } \\
\text { giveaway }\end{array}$ & $\begin{array}{l}\text { Melakuka } \\
\mathrm{n} \text { progam } \\
\text { discount }\end{array}$ \\
\hline & $\begin{array}{l}\text { Jumlah } \\
\text { marketplace }\end{array}$ & $\begin{array}{l}\text { shopee, } \\
\text { whatsapp }\end{array}$ & tokopedia & $\begin{array}{l}\text { tokopedia, } \\
\text { whatsapp, } \\
\text { line }\end{array}$ \\
\hline & $\begin{array}{l}\text { Jumlah } \\
\text { Reseller } \\
\text { distributor }\end{array}$ & $\begin{array}{l}\text { Tidak } \\
\text { memiliki } \\
\text { reseller } \\
\end{array}$ & $\begin{array}{l}\text { Tidak } \\
\text { memiliki } \\
\text { reseller } \\
\end{array}$ & $\begin{array}{l}\text { Tidak } \\
\text { memiliki } \\
\text { reseller } \\
\end{array}$ \\
\hline & $\begin{array}{l}\text { Jumlah toko } \\
\text { fisik }\end{array}$ & Tidak ada & Tidak ada & Tidak ada \\
\hline & $\begin{array}{l}\text { Konten } \\
\text { Instagram }\end{array}$ & $\begin{array}{l}\text { informasi } \\
\text { produk dan } \\
\text { promosi } \\
\text { produk }\end{array}$ & $\begin{array}{l}\text { informasi } \\
\text { produk dan } \\
\text { promosi } \\
\text { produk }\end{array}$ & $\begin{array}{l}\text { informasi } \\
\text { produk } \\
\text { dan } \\
\text { promosi } \\
\text { produk }\end{array}$ \\
\hline & $\begin{array}{l}\text { Frekuensi } \\
\text { posting }\end{array}$ & $\begin{array}{l}0-2 \text { postl } \\
\text { hari }\end{array}$ & $\begin{array}{l}2-5 \text { postl } \\
\text { hari }\end{array}$ & $\begin{array}{l}1-3 \text { post/ } \\
\text { hari }\end{array}$ \\
\hline & Whatsapp & $\begin{array}{l}\text { sebagai } \\
\text { media } \\
\text { pemesanan } \\
\text { produk }\end{array}$ & $\begin{array}{l}\text { Tidak ada } \\
\text { whatsapp }\end{array}$ & $\begin{array}{l}\text { digunakan } \\
\text { sebagai } \\
\text { media } \\
\text { pemesa } \\
\text { nan } \\
\text { produk } \\
\end{array}$ \\
\hline & $\begin{array}{l}\text { Sistem } \\
\text { Packaging }\end{array}$ & & & \\
\hline \multirow[t]{2}{*}{$\begin{array}{l}\text { Sistem } \\
\text { Distribusi }\end{array}$} & $\begin{array}{l}\text { Pengiriman/ } \\
\text { transportasi }\end{array}$ & Kurir & Kurir & Kurir \\
\hline & $\begin{array}{l}\text { Pengaturan } \\
\text { staf } \\
\text { distribusi }\end{array}$ & $\begin{array}{l}\text { Langsung } \\
\text { dari gudang }\end{array}$ & $\begin{array}{l}\text { Langsung } \\
\text { dari gudang }\end{array}$ & $\begin{array}{l}\text { Langsung } \\
\text { dari } \\
\text { gudang }\end{array}$ \\
\hline
\end{tabular}


bisa dibawa untuk berpergian keluar rumah. Desain tote bag ini memiliki fitur beberapa slot di bagian dalam tote bag (tempat botol minum, tempat alat tulis, tempat alat makan, tempat alat sholat, tempat tissue dan masker), satu kantong di bagian luar tote bag (tempat handwash dan disinfektan) dan gantungan untuk wadah hand sanitizer.

Maka kriteria desain yang ditetapkan adalah:

1. Memiliki ukuran yang pas atau sesuai (tidak terlalu besar atau kecil)

2. Menggunakan risleting supaya aman saat membawa banyak barang

3. Bahan lapisan furing suede halus.

4. Memiliki beberapa kantong didalam dan di luar.

\section{Pengembangan Ide (SCAMPER)}

Setelah konsep desain dilanjutkan dengan pengembangan ide. Teknik Scamper dapat digunakan untuk mengubah sebuah produk menjadi produk yang lebih inovatif. Setiap huruf pada kata Scamper menandakan sebuah arti sesuai dengan huruf awal, kata-kata yang memiliki arti tersebut terdiri dari Subtitute, Combine, Adapt, Modify, Put to Another Use, Eliminate, Reverse [10]. Kemudian dari Scamper itu yang akan dipilih:

\section{Combine}

Menggabungkan bahan webbing katun untuk strap pendek dan bagian dalam tas dengan kombinasi bahan drill untuk slot sebagai fitur tempat menyimpan peralatan kebutuhan dengan kain suede untuk furing.

2. Adapt

Penggunaan fitur strap panjang, fitur slot pada bagian dan dalam bagian luar, bahan bagian strap pendek yaitu webbing, bentuk totebag boxy atau persegi panjang, fitur wadah hand sanitizer dan face shieldhat pada produk pesaing akan di adaptasi untuk produk yang akan di re-desain.

3. Modifity

a. Ukuran produk menjadi lebih kecil dari produk sebelumnya

b. Bentuk kantong di bagian depan bisa untuk satu kantong atau beberapa yang menggunakan kancing magnet

c. Modifikasi pada bentuk maker earloop dengan tambahan sambungan berbahan katun untuk jadi masker untuk pengguna berhijab.

Gambar 8 menunjukkan inspirasi produk yang digunakkan yang didapat dari metode SCAMPER.

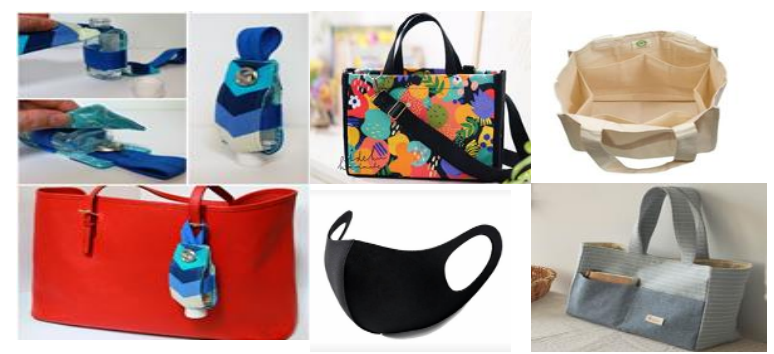

Gambar 8. Inspirasi Produk.

Berdasarkan hasil SCAMPER ini ditambahkan beberapa detail, bentuk yang menjadi inspirasi yang akan hingga hasilnya adalah Desain Platform.

\section{Desain Platfrom}

Dari SCAMPER ini dibuat berbagai desain platfrom seperti dapat dilihat pada Gambar-gambar 9, 10, dan 11. Selanjutnya dari ketiga desain platform, dipilih desain platfrom 1 untuk dikembangkan menjadi desain alternatif.

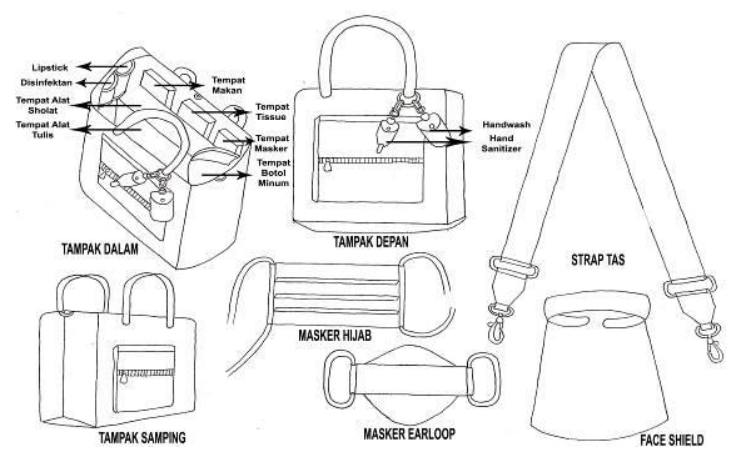

Gambar. 9. Desain Platfrom 1

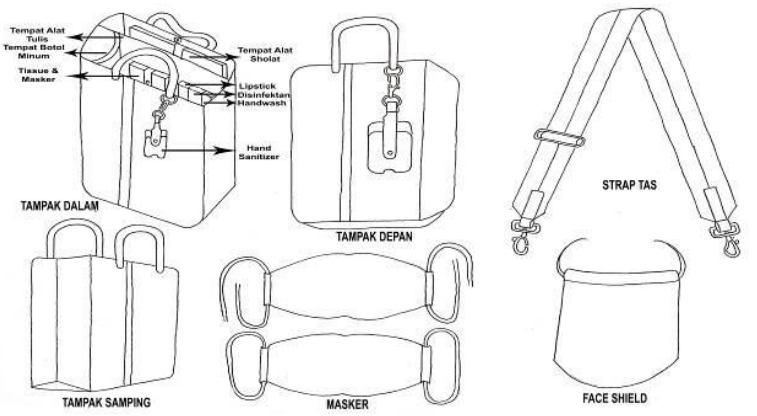

Gambar 10. Desain Platfrom 2.

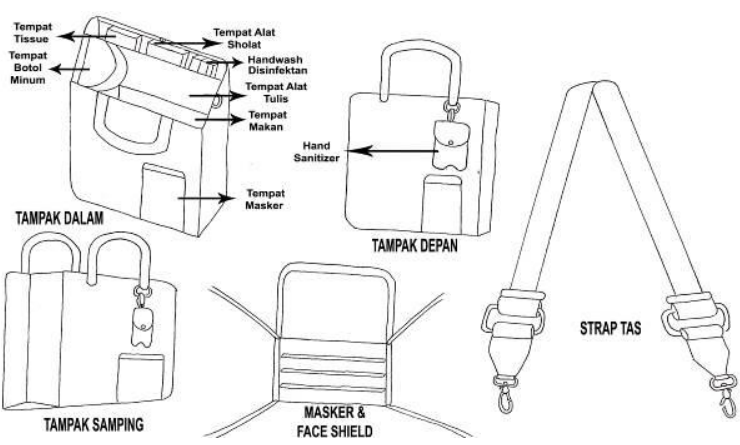

Gambar 11. Desain Platfrom 3.

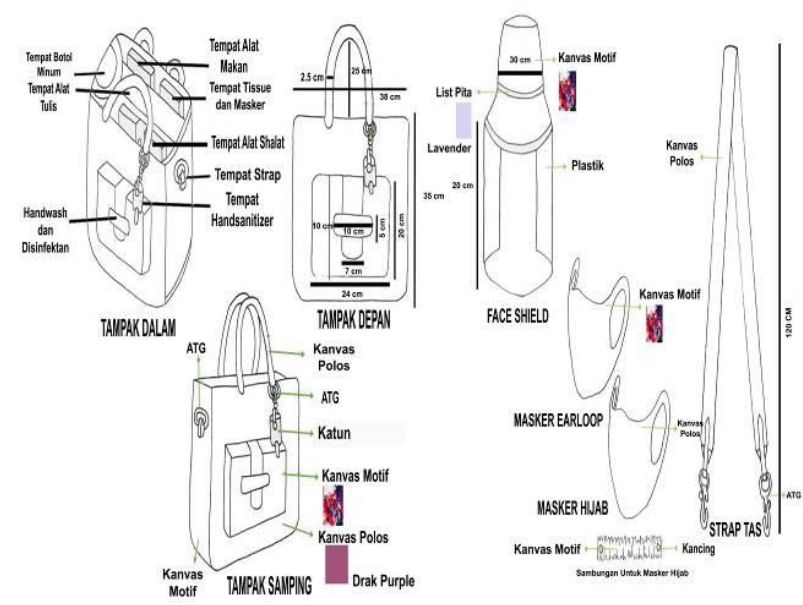

Gambar12. Alternatif desain 1A. 


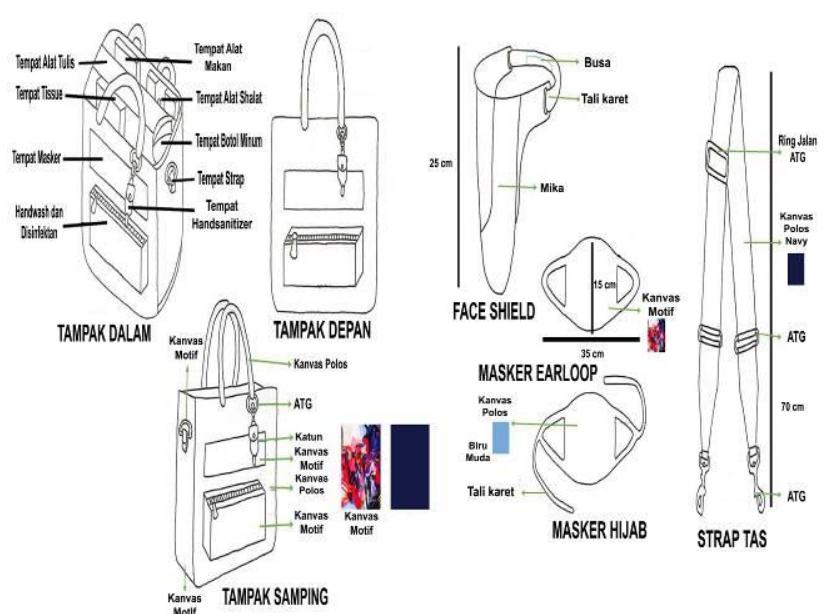

Gambar 13. Alternatif desain 1B.

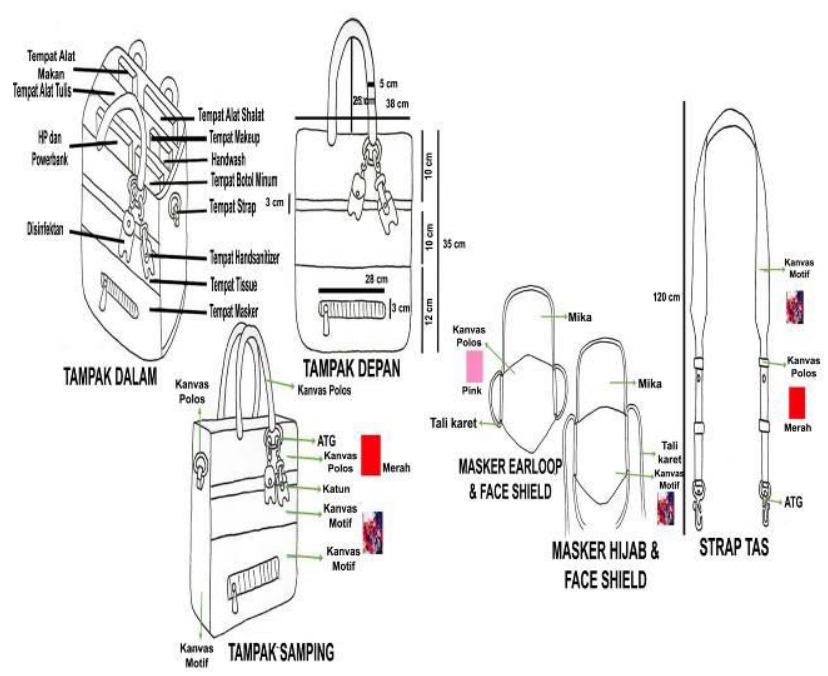

Gambar 14. Alternatif desain 1C.

\section{Alternatif Desain}

Dari platfrom desain ini dibuat berbagai alternatif desain seperti dapat dilihat pada Gambar-gambar 12, 13, dan 14.

\section{Desain Akhir}

Pemilihan desain yang akan dikembangkan menjadi rangkaian desain- koleksi adalah alternatif $1 \mathrm{~A}$. Karena paling sesuai dengan karakter UKM Omorfa Matia dan memiliki fitur-fitur yang sesuai untuk bepergian ke luar rumah di masa new normal. Desain dibuat satu set produk yang terdiri dari tote bag, strap panjang, face shield, wadah hand sanitizer.

Bahan tote bag bagian luar menggunakan full printing canvas motif, bagian dalam kain suede halus berwarna cream dan slot menggunakan kain katun polos warna baby pink, menggunakan ristleting plastik berwarna baby pink dan strap pendek tali webbing warna baby pink.

Terdapat ada dua jenis desain masker, yaitu model earloop dan tali belakang untuk pengguna berhijab. Bahan yang digunakan untuk sambungan tipe masker hijab adalah kain printing canvas dan kancing berwarna cream. Strap panjang menggunakan kain printing canvas motif dan kaitan black nickel. Face shield dibuat dengan menambahkan dengan topi bahan printing canvas yang disatukan dengan plastik mika (Gambar 15).
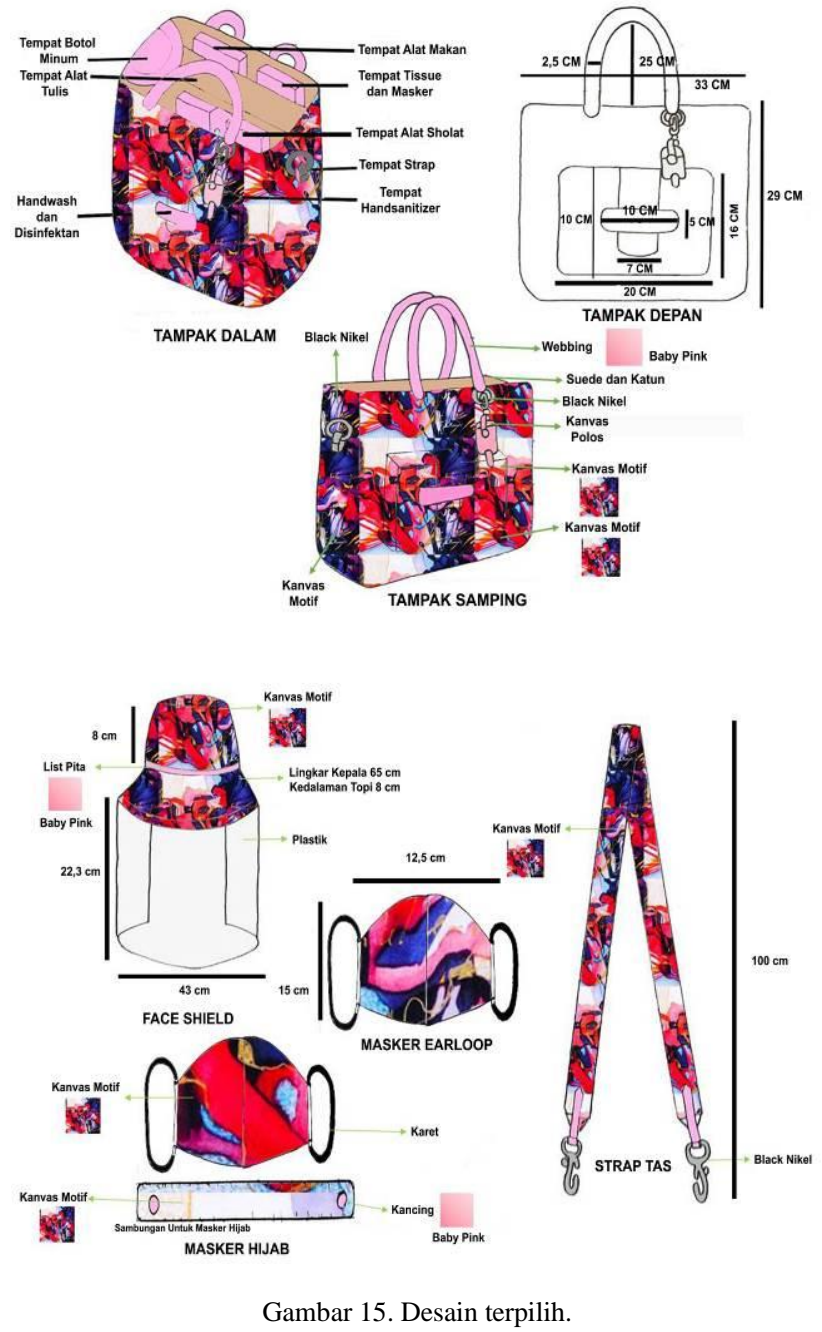

\section{KESIMPULAN/RINGKASAN}

Dapat disimpulkan bahwa produk yang akan diproduksi memeiliki karakteristik sebagai berikut:

1. Produk menggunakan kain printing canvas.

2. Terdiri dari 1 (satu) set produk untuk masa New Normal yang terdiri dari tote bag, strap panjang, face shield, strap panjang, wadah handsanitizer.

3. Tote bag ini memiliki fitur slot di bagian dalam (tempat botol minum, tempat alat tulis, tempat alat makan, tempat alat sholat, tempat tissue dan masker), kantong di bagian luar (tempat handwash dan disinfektan) dan gantungan untuk wadah hand sanitizer.

4. Rancangan produk sedikit berubah dari konsep pada segi materialnya untuk bagian furing awalnya menggunakan bahan spundbond menjadi suede dan slot menggunakan kain katun polos.

\section{UCAPAN TERIMA KASIH}

Penulis mengucapkan terima kasih atas bantuan, bimbingan serta kerjasama dari berbagai pihak yang telah membantu dalam penyusunan artikel ini. Khususnya penulis menyampaikan terima kasih kepada pemilik UKM Omorfa Matia dan dosen mata kuliah Studio DP 4 di Universitas Trilogi Jakarta. 


\section{DAFTAR PUSTAKA}

[1] Fitrianny, Russanti. 2019. Pengaruh Berat Lem Kayu Terhadap Hasil Jadi Aplikasi Kain Goni Pada Tote Bag. Vol .08 No 3. Hal $143-149$

[2] Maulida. F. S. (2016). "Perancangan Motif yang Terinspirasi dari Motif Batik Tasikmalaya untuk Remaja dengan Teknik Digital Printing" e-Proceeding of Art \& Design : Vol.3, No.1 April 2016. Hal. 43

[3] Andriana Y.F . "Digital Printing Motif on Muslim Fashion Trend in Indonesia “. In: Hassan F., Osman I., Kassim E., Haris B., Hassan R. (eds) Contemporary Management and Science Issues in the Halal Industry. Springer, Singapore. (2019)

[4] UU KMK No. HK.01.07-MENKES-382-2020 ttg Protokol Kesehatan Bagi Masyarakat di Tempat dan Fasilitas Umum Dalam Rangka Pencegahan Covid-19

[5] Judianto. O, Hapsari. P.A. (2018). "Perancangan Sepatu Wanita
Ready to Wear Berbahan Kertas Kraft". Jurnal Desain IDEA Vol. 17, No.2, Oktober 2018

[6] Dr. J.R. Raco, M. M. (2010). Metode Penelitian Kualitatif : Jenis, Karakteristik dan Keunggulannya.Cikarang: Grasindo.

[7] Zulhiana. M, Suliantoro. H, Purwaningsih. R. (2016). "Pemilihan Strategi Bisnis Dengan menggunakan Metode Quantitative Srategy Planning Matrix pada UKM Batik Banyumas". Indusrial Engineering Online Journal : Vol. 4, No. 4 April 2016.

[8] Putra Y.S. (2013). "Analisis Matriks Boston Consulting Grup (BCG) Pada Sepeda Motor Milik Honda”. Jurnal Stieama : Vol 7 No.13 2013

[9] Putra. B. P. Y, Wulandari. S, Sagita. B. H. (2019). "Perancangan Progam Komunikasi Pemasaran Tas Pada UKM Levaya Menggunakan Metode Benchmarking”. JISI: JURNAL INTEGRASI SISTEM INDUSTRI : Volume 6 No 2 Agustus 2019

[10] Saputri. S. M, Nursari. F. (2018). "Perancangan Busana Activewear Berdasarkan Trent Forecasting 2019/2020". eProceeding of Art \& Design : Vol.5, No.3 Desember 2018 